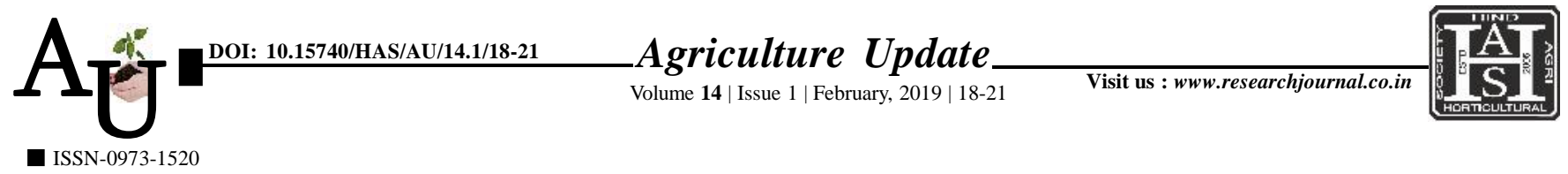

\title{
Rевевсн AвтіLе: Analysis of yield gap and economic performance of Bengal gram through frontline demonstrations in Davanagere district of Karnataka
}

\section{J. Raghuraja}

Article Chronicle:

Received :

12.11.2018;

Revised :

28.12.2018;

Accepted :

04.01.2019

\section{KEY WORDS :}

Frontline demonstrations, Yield gap, Extension gap, Technology gap, Economic

performance
Author for correspondence :

\section{J. Raghuraja}

ICAR-Taralabalu Krishi

Vigyan Kendra,

Davanagere (Karnataka)

India

Email: raghuraja92@

yahoo.com
SUMMARY : ICAR-Taralabalu Krishi Vigyan Kendra, Davanagere has organized front line demonstrations on integrated crop management of Bengal gram in 77 hectares covering 158 farmers in 9 villages for 8 years. The average yield of 3 demonstrated varieties was $744.38 \mathrm{~kg} / \mathrm{ha}$. and that of local check was $522.5 \mathrm{~kg} / \mathrm{ha}$. The average increase of demonstration yield over local check yield was 40.51 per cent. The average technology gap for 3 varieties was $355.62 \mathrm{~kg} / \mathrm{ha}$. and extension gap was 221.88 $\mathrm{kg} / \mathrm{ha}$. In 6 years out of 8 years under study technology gap was more than extension gap. The average technology index for 8 years was 31.57 per cent. The average gross return for demonstration and local check was Rs. 27557.76 and Rs. 19359.00, respectively. The average increase in gross return of demonstration over local check was 41.58 per cent. Average increase in net returns compared to demonstration over local check was 77.23 per cent. The frontline demonstrations on Bengal gram helped farmers to realize higher yield and income.

How to cite this article : Raghuraja, J. (2019). Analysis of yield gap and economic performance of Bengal gram through frontline demonstrations in Davanagere district of Karnataka. Agric. Update, 14(1): 18-21; DOI : 10.15740/ HAS/AU/14.1/18-21. Copyright@ 2019: Hind Agri-Horticultural Society. 